\title{
South Africa's New Constitution: the Challenges of Diversity and Identity
}

\author{
By Heinz Klug
}

\section{Introduction}

The African National Congress (ANC) with its formal nonracial ideology won the first democratic elections. Nevertheless challenges of diversity and identity remain embedded in the interim constitution which went into effect on the eve of the elections at one minute past midnight on April 27, 1994. Furthermore, these issues wait to be reopened as the Constitutional Assembly negotiates the final post-apartheid constitution. In terms of the 1993 Constitution this process must produce a new constitution within two years of the date of the first sitting of the Constitutional Assembly. ${ }^{1}$ The salience of issues of diversity and identity to the constitution-making process, despite a legacy of non-racialism within the ANC, became increasingly apparent as the negotiations unfolded.

As the process of constitution-making progressed claims for the recognition of specific differences or identities became increasingly mobilized. Some of these claims achieved a degree of success in the constitution-making process with significant political consequences. Claims for gender equality, for example, found success not only in a decision to require every party to be represented by at least one women on the Negotiating Council in the 1993 negotiations - in which each party had only two representatives - but the inclusion of a specific Commission on Gender Equality in the 1993 Constitution ${ }^{2}$ means that gender issues will continue to achieve a high degree of recognition as the transition

1 Constitution of the Republic of South Africa Act 200 of 1993, Section 73(1) [hereinafter S. Afr. Const. (1993)].

2 S. Afr. Const. (1993), sections 119 and 120. 
continues. Politically these achievements foreshadowed an even more immediate victory in the decision by the African National Congress to require a one-third quota for women on the organizations list of parliamentary candidates in the April 1994 election. ${ }^{3}$

Despite the successes of women and other claimants who demanded that past and continuing exclusion be addressed by the new constitutional framework, it was the claims for ethnic identities that came to dominate the constitution-making process for the interim constitution. The power of these claims came both from the fact that the claimants had access to state resources and power in different regions of the country and from the threat they posed to the very continuation and success of the democratic transition. Coming together in October 1993 a rather unlikely group of right-wing white parties - committed to the continuation of apartheid or the establishment of a white homeland - and black bantustan parties and governments, who had gained stakes in their regional enclaves created by apartheid's bantustan policy, forged the Freedom Alliance. Despite some awkward moments - for example when neo-fascist AWB members stormed the negotiating venue and assaulted a number of Inkatha delegates - this alliance managed to threaten the election process and obtained a series of concessions from the major parties the ANC and the National Party government - which went some way to accepting the need to address ethnic concerns.

\section{Constitutional approaches to problems of ethnicity}

In order to evaluate the ways in which the 1993 Constitution has addressed or incorporated these issues it is necessary to first identify different possible constitutional approaches to problems of ethnicity and difference and then to consider how the three major players - the ANC, National Party/apartheid government and the IFP - initially proposed to deal with these issues and how they modified their positions in the face of increasing challenges.

Dharam and Yash Ghai, in an analysis of constitutional frameworks designed to tackle problems of ethnicity in South and South-East Asia have identified three distinct 
constitutional approaches. ${ }^{4}$ The first approach assumes that ethnic problems are transitional and that the constitution should not inhibit the necessary process of national integration. By emphasizing representative democracy and the protection of individual rights through a Bill of Rights this approach encourages the formation of a single national identity which is expected to supersede any preexisting regional or ethnic identities.

The second approach assumes that ethnic minorities need more than individual or even group protection against arbitrary discrimination. This approach requires ethnic minorities to have a share in power that will enable each group to participate significantly in decision-making. Among the mechanisms associated with this approach are different forms of power sharing - for example a government of national unity - or more intricate mechanisms such as consociationalism which provides a scheme for overarching cooperation among elites and autonomy for each of the groups over their community's internal affairs. ${ }^{5}$ Although inapplicable to situations where ethnic minorities or other groups claiming recognition and autonomy are not geographically concentrated, federalism is also considered an important means of ensuring participation for particular groups which may by their minority status be democratically excluded at the national level. ${ }^{6}$

The third option is an intermediate position in which specific but limited provision is made to address the concerns of particular communities. These mechanisms may vary from systems of guaranteed representation - as white Zimbabweans received for the first ten years after independence - or the specific protection or recognition of a community's language, religion, culture or even particular forms of land holding or communal lands the existence of which provides the cultural basis for the continued existence of the group. For example the land rights of indigenous populations in Fiji and indigenous communities in remote areas such as the Amazon and Northern Canada have been accorded special

4 See, D. Ghai and Y. Ghai, Ethnicity, development and democracy, in: Peace and Conflict Issues After the Cold War (UNESCO, 1992) at 79; Y. Ghai, Legal Responses to Ethnicity in South and South East Asia (Univ. of Hong Kong, Mimeo); and Y. Ghai, Ethnicity and Governance in Asia: A Report to the Ford Foundation (Draft).

5 See, D. L. Horowitz, A Democratic South Africa? Constitutional Engineering in a Divided Society (1991) at 137-145.

6 See generally, R.A. Dahl, Democracy and its Critics (1989) 197-209; South African Law Commission, Report on Constitutional Models (1991) Vol. 2, at 515-516; G. Gunther, Constitutional Law (10th ed., 1980) at 78-79; and W. B. Graves, American Intergovernmental Relations (1964) at 3-30. 
recognition of this kind. ${ }^{7}$ Significantly, the inclusion of a bill of rights with specific protections for property and the right of communities to control particularly sensitive areas of social life, such as education, may also provide a means to satisfy the needs of particular communities. Reliance on a bill of rights with an emphasis on individual protection and the negative enforcement of rights will however be most effective only in cases where the community is particularly wealthy and thus can provide for itself despite government neglect.

\section{The proposals of the major players in the South African context}

In order to understand the nuances of the 1993 Constitution and the continuing process of negotiations and constitution-making in South Africa it is necessary to outline the initial proposals of the three major players in the process - the African National Congress, the National Party government and the Inkatha Freedom Party. Although only a dramatic change in their respective positions - from the violent imposition and defence of apartheid on the one side and an armed liberation struggle on the other - allowed the process of negotiations to begin, they continued to represent dramatically different approaches which became significantly modified and bound together in the 1993 constitution.

In analyzing these different approaches I will distinguish between their procedural notions of constitution-making on the one hand and their substantive proposals on the other. Each of the three major parties had a distinct notion of the process of constitution-making. The ANC, under pressure from its membership and the democratic movement campaigned for an open democratic process in which a constitution was ideally to be drawn up by an unfetted, democratically elected, constituent assembly. Despite its preference for a democratically controlled constituent assembly, the ANC recognized even as it initiated the process of negotiations in 1988 that the white minority would refuse to enter a democratic transition unless there were some guarantees of the outcome. In order to provide these guarantees the ANC adopted a number of constitutional principles in $1988^{8}$ Michigan J. of L. Reform 547 (1992).

8

African National Congress, Constitutional Guidelines for a Democratic South Africa (1988) reprinted in: The Road to Peace (ANC Dept. of Political Education, June 1990) at 29. 
which it then promoted through the Organization of African Unity ${ }^{9}$ until they were included in United Nations resolutions as conditions to be met by any future South African constitution acceptable to the international community.

The NP government at first resisted calls for a democratically elected constituent assembly arguing that as holders of state power they saw the need for a long transition period in which a future constitution could be negotiated between the parties. Although the Conference for a Democratic South Africa (CODESA) was formed to negotiate the transition to a new constitutional order, the government insisted that it was necessary to have legal continuity and that as such the National Party dominated tricameral parliament $^{10}$ would have to adopt the new constitution. This would require that the constitution be negotiated between the parties and not by a democratically elected body. In fact the government argued that there could be no non-racial election until there was a constitution which would provide for it. For the government any suggestion that there should be a legal break with the apartheid past raised issues of the sovereignty of the South African state and the legitimacy of their position as a de jure government and were thus non-negotiable. Finally, the National Party was determined to project its power - as holder of state power for over forty years - into the future, if not to control the outcome, at least to ensure certain basic property and social interests through the insulation of private power in the post-apartheid order. ${ }^{11}$

The Inkatha Freedom Party argued that the notion of a democratically elected constituent assembly is in itself undemocratic. ${ }^{12}$ In an exercise of astounding formal logic the party argues that the purpose of a justiciable constitution and a Bill of Rights is to protect minorities from the tyranny of the majority. If this is so, the argument goes, then it is necessary for the minorities which are to be protected under this framework to give their

See, Harare Declaration, Declaration of the OAU Ad-hoc Committee on Southern Africa on the Question of South Africa; Harare, Zimbabwe: August 21, 1989 reprinted in: The Road to Peace (ANC Dept. of Political Education, June 1990) at 34.

10 Established in terms of the Republic of South Africa Constitution Act 110 of 1983.

1 See generally, The Long Journey: South Africa's quest for a negotiated settlement (ed. S. Friedman, 1993) at 26-7.

12 See, Inkatha Freedom Party, Why the Inkatha Freedom Party Objects to the Idea of the New Constitution Being Written by a Popularly Elected Assembly (Whether called "Constituent Assembly" or called by any other name), undated submission to Codesa Working Group 2 (1992). 
assent to the particular scheme. This requires all parties which are going to live under this framework to give their prior consent. In other words, the IFP and every other minor party at the negotiating table must reach consensus on the final constitution. ${ }^{13}$

Recognizing the sheer enormity of obtaining universal consensus the IFP argues that the process of constitution-making must be depoliticized and that a group of constitutional experts should be retained to produce the constitution which would then be adopted by the parties and endorsed in a national plebiscite. ${ }^{14}$ The assumption that a constitutional framework is inherently neutral and that its neutrality can be ensured by the appointment of constitutional experts is politically naive, however the IFP's proposal for a national referendum to confirm a negotiated constitution demonstrates a Machiavellian conception of democracy. If all the parties were to reach consensus on a constitution there would be only the shadow of formal democracy in a national plebiscite to endorse the result. All significant opposition to the outcome would have had to be suppressed in order to have achieved the initial consensus. In other words, the IFP argued that unless all political formations - regardless of the extent of their support - agreed to the constitutional framework it would, by definition, be antidemocratic. ${ }^{15}$

Each party's stance on the procedural aspects of constitution-making was also reflected in their substantive proposals. The three major parties were orientated towards their own particular conception of South Africa's future identity. For the ANC a future South Africa must be based on a common citizenship and identity which can only be achieved through a collective effort to overcome apartheid's legacy. ${ }^{16}$ The National Party conceives of a future South Africa in which local communities may voluntarily choose to pursue their own

The "Inkatha Freedom Party has on numerous occasions made clear its objection to an y majoritarian approach to the drafting of the fundamental law of the land. Therefore IFP would insist that even in such interim parliament the rule of consensus should be applied instead of special majority whether such special majority be two-thirds as proposed by the ANC or seventy-five per cent as proposed by the government." Comments of IFP on document of Working Group 2 [Codesa] Steering Committee proposal on CMB [Constitution-making Body] 27 April 1992.

14 See, Position Paper of the Inkatha Freedom Party for Submission at the CODESA meeting of February 6, 1992, reprinted in: Constitutions of the World (eds. A. P. Blaustein \& G. H. Flanz), South African Supplement, Release 92-2 (A. P. Blaustein, March 1992) at 173. See, The Long Journey: South Africa's quest for a negotiated settlement (ed. S. Friedman, 1993) at 16 71.

See, ANC, The Reconstruction and Development Programme (1994) at 1-3. 
living arrangements without interference from the state. ${ }^{17}$ To this goal the NP advocates a government of limited powers and proposes that different communities should be able to veto legislative action - if not directly at the national level then indirectly at the local level through self-government based on local property rights and through the creation of a firewall between public and private activity. ${ }^{18}$ The IFP advocates complete regional autonomy which it describes as "federalism," as a means to ensure the self-determination of particular communities. The IFP's federalism would require not only that national government be a government of limited, enumerated powers but also that the national constitution remain subject to the constitutions of the individual states of the federation. ${ }^{19}$ Although labelled federalism the essence of the IFP proposal is a system of confederation similar to the European Union.

In specific terms the ANC proposed a combination of elements which on the one side would ensure the participation in the legislature of any group that can achieve five percent of the national vote through a system of proportional representation and on the other a series of constitutional provisions designed to address the legacy of apartheid. Although initially committed to a national list system of proportional representation the ANC adopted a system of combined national and regional lists under pressure from its own regions which demanded a greater voice in the process of candidate selection. The constitutional provisions designed to address the legacy of apartheid were contained in the ANC's proposed Bill of Rights ${ }^{20}$ and comprise five different prongs which together would work to produce a system of both formal and substantive equality. The five prongs of this framework are: the guarantee of formal equality; affirmative action; positive measures involving specific constitutional mandates to transform particular state institutions; the guarantee of a progressively expanding floor of minimum socio-economic rights and finally, provision for regional equalization which is designed to address the dualistic structure of South African regional development. This vision - to overcome South Africa's legacy of racial domination and inequality - assumes a substantive interpretation of the framework for a new democratic South Africa (1991); and National Party, Constitutional plan Nationalist, Vol. 11: 9, November 1991 at 12.

18 National Party, Constitutional Rule in a Participatory Democracy: The National Party's framework for a new democratic South Africa (1991) at 15-18.

19 See, Inkatha Freedom Party, The Constitution of the Federal Republic of South Africa (Draft, June 18, 1993), reprinted in Blaustein, Constitutions of the World ANC, A Bill of Rights for a New South Africa (Feb. 1993). 
notion of equality and incorporates a strategy for realizing a constitutional duty originally proposed in the ANC Constitutional Guidelines - to actively eradicate "the economic and social inequalities produced by racial discrimination." 21

Central to this vision is the guarantee of formal equality, asserting - in contradiction to the essence of all prior South African Constitutions - that "all South Africans are born free and equal in dignity and rights." ${ }^{22}$ Article 1 guarantees that "no individual or group shall receive privileges or be subjected to discrimination, domination or abuse on the grounds of race..." ${ }^{23}$ Herein lies the clue to the ANC's conception of equality. If this were to be interpreted in isolation from the draft's other provisions as guaranteeing simply equal treatment then the Bill of Rights would fail to confront apartheid's imposed inequalities. However, when read in the spirit of the entire draft Bill of Rights, it becomes clear that the conception of equality in the draft envisages a process through which equal opportunity is attained by addressing past discrimination and is to be maintained through the guarantee of non-discrimination and "equal protection under the law." ${ }^{24}$

The specific prongs of the ANC's strategy for attaining equal opportunity are: first, the guarantee of formal equality. Taken together with the guarantee of political rights, ${ }^{25}$ including the entrenchment of multi-party democracy to be ensured through "regular, free and fair" ${ }^{26}$ elections, this guarantee makes it clear that legislative power will rest in the hands of the country's majority - a majority which had been excluded from political participation. And although this power will be bounded by individual and collective rights guaranteed in a justiciable bill of rights, a democratically elected government will clearly have the power to introduce legislation and pass laws to improve the lot of the newlyenfranchised victims of apartheid.

Second, the ANC bill proposes an explicit, constitutionally mandated and protected process of affirmative action. Based on the principle of redressing past discrimination, article 14 of the ANC draft facilitates the creation of programs to "procure the (1989) at 323. ANC, A Bill of Rights for a New South Africa (Feb. 1993) at Art.1(1).

Id. at Art. 1(2).

Id. at Art. 1(3).

See, ANC, A Bill of Rights for a New South Africa (Feb. 1993) at Art. 3.

Id. at Art. 3(4). 
advancement and the opening up of opportunities," by both public and private bodies. ${ }^{27}$ The second clause of this article reveals the drafters' textured understanding of the notion of equality. In stating that "any action taken in terms of the above [Art. 14 (1)] shall not be deemed to contradict the principle of equal rights for all South Africans as set out in Article 1," the document makes it clear that the notion of equal treatment guaranteed by article 1 (2) incorporates the prerequisite of substantive equal opportunity. ${ }^{28}$ Article fourteen's protection of affirmative action may thus be understood as guaranteeing a process which will over time confront accumulated and structured patterns of inequality.

Third, there is the adoption of a type of enhanced affirmative action principle in article fifteen's mandate of 'positive measures. ${ }^{29}$ This section of the ANC Bill of Rights moves from a general assertion of the state's duty to promote both racial and sexual equality to the inclusion of very specific mandates to transform the racial composition of the public service - including the 'defence and police forces and the prison service'. ${ }^{30}$ It also makes explicit the right of the legislature to enact laws to require 'non-governmental organizations and private bodies to conduct themselves in accordance with the [articles'] principles. ${ }^{31}$ Provision is thus made for the constitutional mandate of positive obligations or enhanced affirmative action to be applied to private non-state action.

Moreover, the inclusion of a duty to work towards the achievement of social and economic rights, implicit in the adoption of mandatory provisions requiring the state to take action to guarantee a 'progressively expanding floor of minimum rights,' provides the fourth prong in the ANC drafts' confrontation with apartheid's enforced inequalities. ${ }^{32}$ Although the inclusion of these socio-economic rights is seen as essential in confronting South

See, ANC, A Bill of Rights for a New South Africa (Feb. 1993) at Art. 14(1).

Id. at Art. 14(2). It is interesting to note that Article 14(2) was completely rewritten after it was pointed out that the wording of the earlier version, which stated that "no provision of the Bill of Rights shall be construed as derogating from or limiting in any way the general provisions of this article," [ANC 1990 Draft, at Art. 13(2)] was vague and subject to broad interpretation. As the note to the new clause acknowledges, it "was interpreted to mean that the principle of affirmative action would be so powerful as to override all personal rights and freedoms" [Note to Art.14(2), at 15]. This clarification makes it clear that the function of the affirmative action clause "is to supplement and strengthen the equality clause, not to override other provisions of the Bill of Rights" [id.].

ANC, A Bill of Rights for a New South Africa (Feb. 1993) at Art. 15.

Id. at $15(6)$.

Id. at $15(8)$.

See, ANC, A Bill of Rights for a New South Africa (Feb. 1993) at Art. 11(2). In a significant revision from earlier drafts the guarantee of the enforceability of these socio-economic rights has been dropped. The previous draft read, "a progressively expanding floor of enforceable minimum rights." 
Africa's vast inequalities, this prong of the ANC's draft also promises that the new constitutional order will continue to be responsive to the rights and needs of the disadvantaged and less powerf ul beyond the necessary period of affirmative action.

Finally, there is the power to divert resources from the richer to the poorer regions of the country. ${ }^{33}$ Although this power is incorporated in Article 11(4) of the Bill of Rights and is thus closely related to the extension of a minimum floor of socio-economic rights, it has a distinct impact of its own in that it provides for the distribution of resources away from the so-called 'first world' parts of South Africa to the underdeveloped bantustan regions that have been the stepchildren of apartheid.

The National Party government entered the negotiations promising its constituency that the government's bottom-line would be a system of power-sharing designed to secure the interests of different communities - characterized at first racially, then as different ethnic nations and ultimately as distinct minorities. ${ }^{34}$ Attempting at first to provide an acceptable version of the failed "consociationalism" of the 1983 constitution, the NP proposed a revolving presidency and a bicameral legislature with the upper house consisting of "minority representatives" - having veto powers over all legislation.

Its proposals rejected for their reliance on a thinly disguised framework of racial vetoes, the National Party modified its approach demanding an extended period of transition and advocating what it described as "constitutional rule in a participatory democracy." ${ }^{35}$ This proposal promotes a combination of individual rights, communal vetoes and consociationalism. Together these elements produce a framework designed to insulate private interests and action from public power with the net effect of allowing those with the resources and desire to pursue a system of privatized apartheid.

34 ANC, A Bill of Rights for a New South Africa (Feb. 1993) Art. 11(4).

First expressed in racial terms, this notion of power sharing soon evolved into a more intemationally acceptable call for the recognition of minority rights and the assertion that all ethnic groups in South Africa constitute distinct minorities requiring a permanent balancing of political power on the basis of minority representation. See, Draft declaration on the rights of persons belonging to national or ethnic, religious and linguistic minorities, Commission on Human Rights, Resolution 1992/16 of 21 February 1992, reprinted in: Human Rights Facts Sheets No. 18: Minority Rights, United Nations Center for Human Rights.

See, National Party, Constitutional Rule in a Participatory Democracy (1991). 
At the national level the protection of individual rights would generally be restricted to positively enforceable political and civil rights ${ }^{36}$ while legislative power would be dominated by the regionally constituted upper house of a bicameral legislature. Significantly regional representation, while analogized to the system of equal state representation in the Senate of the United States of America, would in fact involve a second level of equivalence which would ensure "minority" veto power. While the regions would be represented by an equal number of representatives, each region's delegates would be made up of an equal number of representatives from every political party achieving more than five percent of electoral support in the region. ${ }^{37}$ The effect of this scheme would be to ensure that parties representing racial or ethnic minorities would receive enough seats in the Senate to effectively veto any legislation threatening their interests accumulated under apartheid.

Relying on this particular construction of a bill of rights and federalism to protect individual and community interests at the national level the focus shifts to the local level where a system of local government, conceived as a form of consociationalism based on property rights, is advocated as a means of securing "participatory democracy." ${ }^{38}$ According to this proposal votes for local government will be apportioned equally between a general voters roll and one restricted to property ownership within each voting district. ${ }^{39}$ Thus despite the fact that formerly, even in apartheid's exclusively "white" suburbs resident African employees made up a large proportion of the residential population, voting rights for local government would be effectively weighted in favor of property holders.

Local government under this proposal would consequentially reflect a consociational model where the different racial groups consigned by apartheid to different geographic areas would each have control over their local arrangements. This pattern would be further exacerbated by the proposal that a "geographical neighbourhood" have the option to exercise "self-determination over community interests" by establishing a Neighbourhood Council entrusted with autonomous powers over "local matters" including security, property use, communal facilities and, with legislative approval, functions such as education and welfare. ${ }^{40}$ Participation in this framework would - given the fact that the

See, Government's Proposals on a Charter of Fundamental Rights (Feb. 2, 1993).

National Party, Constitutional Rule in a Participatory Democracy at 12 (1991).

Id. at 16.

Id. at 17.

National Party, Constitutional Rule in a Participatory Democracy at 17-18 (1991). 
geographic patterns of segregation enforced by apartheid are likely, with the slow movement in property ownership, to remain relatively stable into the immediate future give rise to an essentially racially based form of political access.

While the National Party seems to have focused its concern on local control the Inkatha Freedom Party early on committed itself to the consolidation of its interests in one region of the country, KwaZulu/Natal. Although at the beginning of the negotiations process the IFP asserted itself as a third major player demanding parity with the ANC and the National Party government, it retreated to the advocacy of regional autonomy in an attempt to perpetuate its existing advantage as a bantustan government into the postapartheid era. ${ }^{41}$

Describing its proposals as federalism - 'just as in the United States of America' - the form of regional autonomy advocated by the IFP and its allies in the Freedom Alliance (consisting of various bantustan parties and pro-apartheid white parties) was closer in substance to the form of state autonomy contained in the United States Articles of Confederation and was more confederal in substance than the present European Union. In terms of the IFP's notion of federalism the different regions of South Africa would constitute autonomous states whose constitutions would dictate interpretation of the "federal" constitution. ${ }^{42}$ In other words, any application of the federal constitution to issues within a region or to conflicts between regions would have to be consistent with the constitutions of the relevant regions. ${ }^{43}$

This conception of "autonomous federalism" is further revealed in the IFP's proposed constitution of KwaZulu/Natal. Declaring the sovereignty of KwaZulu/Natal to be "indivisible, inalienable and untransferable," ${ }^{44}$ the proposed constitution would: require South African armed forces to obtain permission before entering Natal; ${ }^{45}$ require South

41

See M. Ottaway, South Africa: The Struggle for a New Order (1993) at 64-72. See, Inkatha Freedom Party, The Constitution of the Federal Republic of South Africa (Draft, June 18, 1993), at Art. 92, reprinted in: Blaustein, Constitutions of the World.

Setting out the jurisdiction of the Constitutional Court the article provides in part that the "resolution of conflicts between Federal Republic of South Africa and the member States to be conducted in a fashion consistent with the provisions of the constitutions of the member States."; Inkatha Freedom Party, The Constitution of the Federal Republic of South Africa (Draft, June 18, 1993) Art. 92.

Art. 3, The Constitution of the State of KwaZulu/Natal, Dec. 1, 1992.

Id. at Art. 67(b). 
Africa to obtain consent before levying tax; ${ }^{46}$ create an "autonomous" Central Bank; ${ }^{47}$ and grant the KwaZulu/Natal Constitutional Court exclusive jurisdiction to decide whether South African laws are valid within the region. ${ }^{48}$

At the federal level the IFP proposes a government of limited powers in specific areas including a common monetary system, national defence, nationality and immigration, foreign affairs, federal judicial organization, intellectual property rights and external commercial relations. ${ }^{49}$ The national legislature is further empowered to pass general principles of legislation in the areas of environmental regulation, banking, interstate commerce and economic development as well as a framework to facilitate intrastate negotiation over policies in these areas. ${ }^{50}$ Finally, any federal legislation would have to be passed by both houses of Parliament effectively giving the Senate - made up of four representatives elected from each state - a final veto over national legislation. ${ }^{51}$

The federal government would be further disempowered under the IFP's proposals by the creation of a series of independent commissions through which to control and regulate federal government activity. Apart from a number of internationally recognizable bodies such as a Judicial Service Commission, ${ }^{52}$ Civil Service Commission ${ }^{53}$ and Electoral Commission$^{54}$ the proposal introduces the notion of independent policy-making institutions into the heart of traditionally government controlled activities such as economic regulation. The proposal calls for the establishment of a series of such commissions including a Privatization Commission, ${ }^{55}$ Regulatory Relief Commission ${ }^{56}$ to repeal or amend burdensome, unnecessary or inadequate regulations - an Environmental Commission, ${ }^{57}$ Consumer Affairs Commission ${ }^{58}$ and finally an Economic

46

Id. at Art. 67(d).

Id. Art. 81.

Id. at Art. 67(c) and Art. 77.

Inkatha Freedom Party, The Constitution of the Federal Republic of South Africa (Draft, June 18, 1993) Art. 65(a).

Id. art. 77.

Id. art. 70(a).

Id. art. 75 .

Id. art. 83 .

Id. art. 84.

Id. art. 81 .

Id. art. 85.

Id. art. 87.

Id. art. 88. 
Development Commission. ${ }^{59}$ A significant feature of these commissions is that their membership is appointed from a variety of sources including the President, federal parliament and private bodies including the national Chamber of Commerce, consumer groups and representatives of industry. ${ }^{60}$ This introduction of different factions into the heart of government is a unique aspect of the IFP proposal, which in the South African context would work to promote established interests whose racial character is largely the product of apartheid's allocation of economic and social resources.

\section{Negotiating the 1993 Constitution}

In the process of negotiating the 1993 constitution there were significant changes in the positions of the three major players as well as important continuities which became cobbled together in the interim constitution. Most fundamentally, the ANC's initial demand for a unitary state came to be interpreted in the sense of national sovereignty over the 1910 boundaries of South Africa rather than in its initial meaning of a central government with preemptive power over regional authorities. With this new emphasis the issue of federalism, rejected initially by the ANC because of its historic association in South Africa with the white opposition Democratic Party and the emasculation of governmental powers, became a central feature of the constitutional debate. Significantly, this shift was not inconsistent with the ANC's own internal organizational experience in which its ten regions were constitutionally represented on the National Executive Committee and possess a degree of constitutional autonomy consistent with a federal structure.

The adoption of the language of "strong regionalism" by both the $\mathrm{ANC}^{61}$ and the National Party government also reflected the National Party's acceptance that the absolute veto powers of the upper house of the legislature would be limited to regional matters and its notion of political party based consociationalism would be formally restricted to local government structures. Although the National Party government accepted the demise of its proposals for a rotating presidency and equal representation in the Senate, many of the provisions of the 1993 constitution, and in particular its guarantee of a five year

59

60

61 See, Id. arts. 81(a), 85(a), 86(a), 87(a) and 88(a).

1 See, ANC Constitutional Committee and Department of Local and Regional Govemment and Housing, ANC Regional Policy: Draft Discussion Document (October, 1992). 
government of National Unity, satisfied many of the goals implicit in the government's earlier proposals.

Unlike the ANC and the National Party government, however, the IFP refused to concede its central claim to regional autonomy and in its alliance with white pro-apartheid parties continued to threaten to disrupt the transitional process. Although factions of the IFP seemed ready to contest the elections for the Natal regional government, the party's leader Chief Gatsha Buthelezi interpreted his parties poor showing in pre-election polls as cause to promote an even more autonomous position encouraging and supporting King Goodwill Zwelethini in his demand for the restoration of the nineteenth century Zulu monarchy with territorial claims beyond even the borders of present-day KwaZulu/Natal.

\section{The 1993 Constitution}

The 1993 Constitution provides a series of contingent constitutional frameworks. Apart from the distinction between the "interim" constitution itself and the provisions providing for the formation and guidance of a new constitution-making body, the 1993 constitution provided alternative constitutional frameworks which would have created an interim government if the April 1994 elections had failed. ${ }^{62}$ However, once the Independent Electoral Commission declared a free and fair election the 1993 Constitution came into substantive effect and the executive structure of a government of national unity was guaranteed for a five year period from April 27, 1994. ${ }^{63}$ The substantive provisions of the 1993 Constitution are however also transitional in that they provide both for a government of national unity and a two year process of constitution-making aimed at achieving a lasting democratic constitution for South Africa.

A survey of the "interim" constitution demonstrates how the different political and constitutional strands advocated by the three major players in the negotiations were spliced together to achieve this transitional structure. The effect of this process is a constitution within which at least two distinct constitutional traditions and other incongruous elements have been melded. Conflicting meanings and emphasis which the different parties asserted while negotiating this framework have now become bound up in the interim constitution. 
This then sets the stage upon which the constitutional court, an entirely new institution in the South African context, will be thrust. Different parties will in litigation and constitutional politics attempt to assert the preeminence of those elements which support their conception of the constitution. Areas of contestation within which the different parties are likely to continue to assert their own particular meanings include: (1) the relationship between negotiated constitutional principles and a democratic constituent assembly; (2) constitutional supremacy and regional constitution-making powers; (3) fundamental rights and substantive equality, especially with respect to affirmative action, property and the proposed inclusion of socio-economic rights in the final constitution; (4) fundamental language and cultural rights, recognition of indigenous law and gender equality; (5) the geographic division of legislative authority and the distinction between exclusive, concurrent and residual powers; (6) the functional division of legislative powers and regional autonomy; (7) proportional representation, power-sharing, consultation and consensus in executive decision-making; (8) fundamental rights to equal political participation and consociational mechanisms based on property at local government level; and finally, (9) effective governance and the proliferation of independent mechanisms of checks and balances. It is around these potential foci of contestation, inherent in the new Constitution, that the constitutional politics and adjudication of the new South Africa will most likely congeal.

\subsection{Negotiated principles and a democratic constituent assembly}

The first nexus of conflict identified - between adherence to constitutional principles and a democratic constitution-making body - was the tension most explicitly addressed both in the negotiations and within the terms of the 1993 Constitution. Citing the need for legal continuity and minority guarantees the national party government long insisted on the need for the entrenchment of at least constitutional principles. Although formally at odds with the ANC's demand for a democratic constituent assembly, the ANC also accepted the need to provide certain assurances as to the future constitutional framework before the National Party government could be expected to willingly enter a process within which it was guaranteed to loose power. ${ }^{64}$ The difficulty arises however in the fact that although the national party government accepted that a new constitution would fail to gain popular

64

See, The Long Journey: South Africa's Quest for a Negotiated Settlement (ed. S. Friedman, 1993) at 62. 
acceptance unless it was adopted by an elected constitution-making body, it attempted to ensure that the constituent body would be bound to produce a constitution within a framework acceptable to the national party.

When an attempt to require a seventy-five percent majority to pass a new constitution within the constitution-making body led to the collapse of negotiations within the CODESA framework, ${ }^{65}$ the parties eventually accepted a compromise which requires the constitutional court to certify that the proposed constitution is consistent with the constitutional principles contained in the 1993 constitution. ${ }^{66}$ As a result, the different parties began to focus their negotiating efforts on the content of the constitutional guarantees as a way of continuing their struggles for particular outcomes with respect to regional powers and racially or ethnically defined governance under the rubric of selfdetermination. The constitutional principles included in schedule four of the 1993 Constitution however remain open to differing interpretation with much scope for conflict between the Constitutional Assembly, political parties, regional entities, and the constitutional court. These potential conflicts pose the risk of embroiling the newly established constitutional court in direct political conflict with the danger of undermining the court's ability to establish its own credibility as a mediating institution.

\subsection{Constitutional supremacy and regional constitution-making}

The second tension, between the supremacy of the national constitution and the status of regional constitutions, while a standard problem of federal-type constitutions, involves a range of intricate distinctions which remain to be resolved. First, although the national constitution is supreme, only the constitutional court has constitutional review jurisdiction over acts of parliament, all other divisions of the supreme court - regional and appellate only have constitutional review jurisdiction over provincial and local legislation. Second, the regions are constitutionally empowered to write their own constitutions providing for their own systems of government and constitutional rights. Before long this will raise the issue of jurisdiction over the interpretation of provincial constitutions and their interaction with the national constitution. Will the constitutional court have jurisdiction to interpret a provincial constitution or will that power lie with a provincial supreme court provided for

65 66

See, The Long Journey: South Africa's Quest for a Negotiated Settlement (ed. S. Friedman, 1993) at 31.

S. Afr. Const. (1993) section 71(2). 
as a separate system of courts in the as yet undefined provincial constitutions? Although it may be possible to accommodate differing provisions in which certain rights are more extensive at the regional level this throws up the problem of conflicts between different forms of rights. This is particularly the case where some regions may wish to advance or even privilege certain group rights to language, culture or indigenous practices of governance and law which are contained, for example, in the African Charter on Human and Peoples' Rights. ${ }^{67}$ A clash will surely arise in cases where the regional constitution privileges cultural autonomy and where individuals challenge certain cultural practices as violating their individual rights guaranteed in the national constitution. Again, although constitutional adjudication may employ sophisticated jurisprudential techniques to balance these different claims the underlying claims are based on very different conceptions of rights as represented in the claims for group self-determination advocated by the Freedom Alliance and notions of national self-determination traditionally accepted in international law and advanced by the African National Congress.

\subsection{Fundamental rights and substantive equality}

The third tension is between notions of fundamental rights on the one side and the promise of state action to address apartheid's legacy on the other. Fundamental rights including; to freely engage in economic activity, and to acquire and hold rights in property will need to be understood in the context of the constitutions explicit acceptance of "measures designed to achieve the adequate protection and advancement of persons or groups or categories of persons disadvantaged by unfair discrimination, in order to enable their full and equal enjoyment of all rights and freedoms." 68 Again the court may be called upon to strike a balance between the vision of substantive equality and the need to deal with the legacy of apartheid as understood in the ANC's constitutional vision and the claims of those who apartheid has enriched to the continued unfetted enjoyment of their accumulations. Practically, these conflicts will arise over questions of: taxation, as has already occurred in the debate over a reconstruction tax or levy based on the post World War II equalization tax in the Federal Republic of Germany; ${ }^{69}$ the allocation of government resources, such as attempts to insulate the current allocation of government contracts from affirmative action by the institution of independent tender boards at every 
level of government; ${ }^{70}$ and redistributive policies designed to narrow the extreme inequalities in social services, health and educational facilities, social and physical inf rastructure and wealth which are the most visible legacies of apartheid.

\subsection{Language, culture, indigenous law and gender equality}

These initiatives will be further complicated by assertions of fundamental cultural and language rights which, bound as they are with issues of self-determination and ethnic identity, will already be politically sensitive areas of contestation. Within this area the direct clash between claims for the recognition of indigenous law and practice, including the recognition of traditional authorities in the area of local governance poses a direct threat to the Constitutions promise of even formal gender equality. Although this issue has already arisen and been explicitly accommodated - the constitution recognizes indigenous law but makes it subject to the constitutional guarantees of individual rights including gender equality ${ }^{71}$ - the possibility of reopening this issue through the assertion of cultural rights is not however excluded. Despite the jurisprudential complexity of these issues they may at least be understood as being capable of judicial resolution on a case by case basis. The set of contested areas related to political participation are however more fraught in their political ramifications and sources of resolution. Although the constitutional court will have jurisdiction over these issues through its power to interpret the constitution, in fact many of these issues will remain contested in the political arena having as great an impact on constitutional politics as on the courts jurisprudential agenda.

\subsection{Geographic division of legislative authority}

The first of these issues of political authority and participation involves the exact definition of the legislative powers which are to be devolved to the provinces. Although the protagonists of a federal solution for South Africa advocated a national government of limited powers the 1993 Constitution reversed the traditional federal division of legislative powers by allocating enumerated powers to the provinces. This allocation of regional powers according to a set of criteria incorporated into constitutional guidelines and in those sections of the constitution dealing with the legislative powers of the

71 S. Afr. Const. (1993) section 187

See, S. Afr. Const. (1993) Schedule 4, Constitutional Principle XIII. 
provinces was however rejected by the IFP on the grounds that the constitution failed to guarantee the autonomy of the provinces. Despite the ANC's protestations that the provincial powers guaranteed by the constitution could not be withdrawn the IFP pointed to the fact that the allocated powers were only concurrent powers and that the national legislature could supersede local legislation through the establishment of a national legislative framework covering any subject matter. This tension between provincial autonomy and the ANC's assertion of the need to establish national frameworks guaranteeing minimum standards and certain basic equalities led to an amendment to the 1993 Constitution before the constitution even came into force. According to the amendment the provinces are now granted exclusive powers in those enumerated areas of legislative authority. ${ }^{72}$ Areas deemed of exclusive jurisdiction to provincial legislatures include: agriculture; gambling; cultural affairs; education at all levels except tertiary; environment; health; housing; language policy; local government; nature conservation; police; state media; public transport; regional planning and development; road traffic regulation; roads; tourism; trade and industrial promotion; traditional authorities; urban and rural development and welfare services. Difficulty arises in this context in distinguishing the exact limits of a regions exclusive powers and the extent to which the national legislature is able to pass general laws effecting rather broad areas of governance. Although the provinces have the power to assign executive control over these matters to the national government when they lack administrative resources to implement particular laws, the Constitution provides that the provinces have executive authority over all matters over which the region has legislative authority as well as matters assigned to the provinces in terms of the transitional clauses of the constitution or delegated to the provinces by national legislation. The net effect of these provisions will be a continued tension between potentially hostile provincial governments and the national government over the extent of regional autonomy and the exact definition of their relative powers. The constitutional courts role in this potential struggle between regional autonomy and the establishment of minimum national standards or frameworks will be further complicated by the constitutional provision entitling each province to an equitable share of nationally collected revenue, a determination which is made according to both enumerated constitutional criteria and the recommendations of the constitutionally established Financial and Fiscal Commission. ${ }^{73}$ See, S. Afr. Const. (1993) section 155 as amended by s. 3 of Act No. 2 of 1994. 


\subsection{Functional division of legislative powers}

This division of legislative power between the national and provincial levels is also reflected in an innovative division of powers along functional lines at the national level. Parliament, which will be made up of a National Assembly of 400 representatives elected by proportional representation ${ }^{74}$ from lists of candidates selected both nationally and regionally will also have a ninety member senate which will be nominated by political parties on a basis of proportional representation from the representatives of the provincial legislatures. $^{75}$ This avenue for regional representation at the national level is further enhanced by the functional division of legislative powers - into general, money, constitutional and regional - between the two houses of parliament. ${ }^{76}$ General bills may be introduced in either house and must be passed by both houses of parliament, however in the event of a failure by either house to pass a general bill the law may still be passed by a simple majority vote of parliament at a joint sitting of the two houses. ${ }^{77}$ Finance bills may only be introduced in the national assembly and if vetoed by the Senate may be passed by a simple majority of the national assembly after a thirty-day waiting period. ${ }^{78}$ Bills affecting regional matters such as provincial boundaries, powers or functions must be passed by both houses sitting alone thus giving the Senate an effective veto power over regionally related matters. This power is further enhanced in the case of bills affecting a single region in which case the senators of that region must agree to the bill. ${ }^{79}$ Thus an aspect of consociationalism or enhanced federalism is retained at the national level in order to frustrate actions aimed at subverting the interests of any particular region. Finally, constitutional amendments require a two-thirds majority of the total membership of both houses. ${ }^{80}$ Although a valuable mechanism for ensuring regional representation and participation in national affairs this functional division will provide a fertile area for contestation. On the one hand one can imagine ample grounds for arguing that a significant proportion of legislation will have an affect on regional powers and functions and thus require Senate approval. On the other, this functional division of legislation opens the possibility of contesting whether any particular bill is of a general nature or whether its financial implications make it a finance bill with the resultant effect of

74

75

76

77

78

79

80

See, S. Afr. Const. (1993) section 40(1).

S. Afr. Const. (1993) section 48(1).

S. Afr. Const. (1993) section 59-62.

S. Afr. Const. (1993) section 59(2).

S. Afr. Const. (1993) section 60(1), (7) and (8).

S. Afr. Const. (1993) section 61.

S. Afr. Const. (1993) section 62(1). 
empowering the national assembly. The net effect of this functional division of legislative power introduces the novel possibility of constitutional contestation and even adjudication between the different houses of parliament.

\subsection{Proportional representation, power-sharing, consultation and consensus}

At the executive level the 1993 Constitution establishes a system of proportional powersharing or what is termed a government of national unity. Not only is this form of government entrenched for the life of the 1993 Constitution but is guaranteed through its inclusion in the constitutional principles governing the constitution-making body until the year 1999. ${ }^{81}$ Although the ANC publicly rejected the national party's demand for powersharing it was the ANC which in late 1992 proposed this particular compromise in order to advance the transitional process. ${ }^{82}$ The constitutional framework created by this system of proportional power-sharing formally applies a highly restricted notion of consociationalism in that the different parties represented in the executive will only be represented according to the proportion of seats they win in the national vote. ${ }^{83}$ Under this structure the ANC would control the majority of the cabinet positions however other provisions ensure that a more robust form of consociationalism has in fact been preserved for the first five years of life of a democratic South Africa.

Despite the limited power proportionality would bestow on minority parties in the cabinet, the provision granting the next largest party in parliament the right to appoint one of the two deputy-presidents contains within it the source of much greater consociational power. This power stems from the requirement in section 233(3) of the constitution's chapter on general and transitional provisions that any functionary required by the constitution to take a decision in consultation with another functionary must obtain the concurrence of such other functionary. The effect of this provision is that the President must obtain the concurrence of the head of the second largest party in parliament in order to make decisions on a list of specific competencies listed in the constitution. Furthermore, the President must obtain the concurrence of the multi-party cabinet or at least the relevant cabinet minister where the cabinet has delegated its power of concurrence before acting in 
any matter. A significant twist in this concurrence requirement is the provision for bodies to reach concurrence through their own decision-making process, in other words the cabinet could reach concurrence by a simple majority vote of the body. ${ }^{84}$

This system of consensus decision-making introduced into the executive branch through the constitutions definition of "in consultation" weights the functioning of the constitution over towards the more formal consociational models which were rejected in the negotiations. Whether the power to deny concurrence gives the second largest party in parliament a veto power over executive action in some areas will remain contested and in the event of deadlock is likely to lead to constitutional litigation, again posing significant difficulties to an incipient constitutional court. Furthermore, the notion of a government of national unity is not restricted to the national government but is repeated again in different forms at the provincial and local level. ${ }^{85}$

\subsection{Political participation and consociational mechanisms}

These hidden consociational aspects of the 1993 constitution reveal themselves again in the potential tension between the guarantee of equal political participation and the constitution's adoption of a form of local government which while being more explicit in its prescription of consensus in decision-making among the parties on a local government's executive council, creates an even more explicit form of consociationalism through the division of the local government electoral mechanism into both a proportional representation and ward system. ${ }^{86}$ The Constitution provides for local government to be democratically elected ${ }^{87}$ and entitles people to register to vote who are either resident in a particular locality or have a legal duty to pay property taxes (rates), rent, service charges or levies to that particular local government. ${ }^{88}$ Combined with the limitation that no voter may have more than one vote per local government, ${ }^{89}$ this provision implies that property owners and lease holders will be able to vote in more than one local government election.

84

85 S. Afr. Const. (1993) section 233(3).

See, S. Afr. Const. (1993) sections 149(2), (3), (4), (5) and (6) for the application of the government of national unity concept to provincial government and sections 176 and 177 for its application to local government.

86

87 S. Afr. Const. (1993) section 245(3).

88 S. Afr. Const. (1993) section 179(1).

88 S. Afr. Const. (1993) section 179(3).

89 S. Afr. Const. (1993) section 179(4). 
Taking this further the transitional provisions divide the allocation of wards - which will elect sixty percent of local government officials - for the first post-apartheid local government election on a fifty/fifty basis between those areas previously designed as African residential areas and those areas designated either white, coloured or Indian under the 1961 constitution. ${ }^{90}$ Furthermore, voting at the ward level will be in terms of the firstpast-the-post system guaranteeing that the geographic racial segregation created by apartheid will most likely determine the composition of the majority of local government councils. The net effect of this allocation of local government voting power will be a system of consociational local government. At least thirty percent of the seats of a local council in any urban area outside of the former bantustans will be effectively guaranteed to representatives of those racial minorities segregated geographically into those wards by apartheid until such time as over fifty percent of residents in any such area decides to vote on non-ethnic lines, or the area has been effectively integrated. This will also guarantee that racial minorities retain approximately a third of the positions on any such local government executive committee given the proportional method of executive appointments.

Although these consociational principles do not violate the constitution's guarantee of free political activity it may very well be argued that even a limited constitutional guarantee of formal equality is violated on two separate grounds. First, since apartheid limited the right of eighty-seven percent of the population to own land property, enabling property holders to vote in every local government election where they hold property and are registered to vote is a prima facie case of political inequality based on apartheid's legacy. Second, where cities and towns are divided into an equal number of wards based on a previous apartheid geography, the numbers of voters in each ward on the black side of town will be significantly greater than the numbers in each ward on the previously white side of town. The effect in this case is a disproportionate weight in the value of the vote on the one side of town providing yet another prima facie case of political inequality. Although with forty percent of the seats elected on the basis of proportional representation this disproportionate weighting among representatives of a local government will be slightly counterbalanced, the fact remains that unless the constitution provides an explicit exception to its equality clause in favor of non-discriminated against groups, these consociational aspects of the proposed local government system may be subject to constitutional challenge. 


\subsection{Effective governance and the proliferation of checks and balances}

Acutely aware of the dangers of governmental abuse of power the different parties to the making of the 1993 Constitution agreed to the inclusion of a vast range of constitutional mechanisms designed to disperse and control the exercise of power. These mechanisms may be characterized on the one hand as checks and balances while on the other they include the establishment of a range of independent entities designed to control specific aspects of governmental power; to advance participation and the exercise of human rights and to ensure the representation of particular social elements in the structures of power.

Among the specific checks and balances included in the constitution are: the Senate's power to delay specific legislation and to veto legislation which may effect the provinces $;{ }^{91}$ an independent Public Protector; ${ }^{92}$ an independent Auditor-General; ${ }^{93}$ a Public Service Commission; ${ }^{94}$ a Judicial Service Commission; ${ }^{95}$ an all-party Parliamentary standing committee to oversee the National Defence Force ${ }^{96}$ independent tender boards $^{97}$ and a Financial and Fiscal Commission. ${ }^{98}$

With different functions and powers these various elements may be divided into four forms. First, the Senate's power to both delay legislation and to veto legislation in some limited circumstances is a traditional element in any bicameral system of checks and balances ensuring that certain matters receive either closer scrutiny or where a particular interest - the provinces - is given the power to prevent a national directive on a matter effecting that interest in a particular way - here its executive, legislative or geographic autonomy.

Another form is the increasingly popular ombuds system represented in the 1993 Constitution by two separate elements, the independent Public Protector and the independent Auditor-General. As a classic ombud the Public Protector is empowered to investigate and to resolve disputes by mediation and negotiation or to advise complainants

91

92 See, S. Afr. Const. (1993) sections 59, 61 and 62.

93 S. Afr. Const. (1993) sections 110-114.

S. Afr. Const. (1993) sections 191-194.

94 S. Afr. Const. (1993) sections 209-211.

95 S. Afr. Const. (1993) section 105.

96 S. A fr. Const. (1993) section 228(3).

97 S. Afr. Const. (1993) section 187(1).

98 S. Afr. Const. (1993) sections 198-206 
of their rights, or to refer a matter to the relevant public of ficials for legal action in cases of maladministration, corruption and acts of omission by public functionaries. The independent Auditor-General on the other hand shall audit and report on all accounts and financial statements at all three levels of government, national, regional and local. In addition the Auditor-General's office may be requested by the President or Parliament to do performance audits, or in response to a complaint investigate and report on any statutory body or other institution in control of public funds. ${ }^{99}$ Significantly, although the Auditor-General reports back to the authorities concerned and to Parliament each year, the constitution requires that these reports shall be made public fourteen days after their submission to the appropriate authority. ${ }^{100}$

The third form is based on the guaranteed participation of all formal political factions concerned with the particular decision-making process. The Financial and Fiscal Commission for example is appointed by the President but also has one representative designated by each provincial executive council. ${ }^{101}$ Although it is designed to render advice and make recommendations to the relevant legislative authorities on the distribution of financial resources between the different levels of government, the constitutional requirement that the Commission be consulted prior to the allocation of revenue and that its recommendations be taken into account will give significant weight to the Commissions' advocacy. More in the mold of an oversight committee the Parliamentary standing committee to oversee the National Defence Force also provides for the participation of all political parties in the control of a vital state institution.

The constitutional provision of non-partisan professionally dominated bodies with powers to regulate the appointment of of fice holders in vital sectors of the state such as the Judicial Service Commission and the Public Service Commission - which also has powers to intervene in the functioning of the civil service - is yet another form of check on governmental action.

Separate from the regular forms of checks and balances the provisions in the constitution for the establishment of a Human Rights Commission ${ }^{102}$ and a Commission on Gender Equality ${ }^{103}$ are examples of mechanisms designed to advance the spread and enjoyment of

100 S. Afr. Const. (1993) sections 193(3) and (4).

101 S. Afr. Const. (1993) section 193(8).

102 S. Afr. Const. (1993) section 200(b).

102 S. Afr. Const. (1993) sections 115-118.

103 S. Afr. Const. (1993) sections 119-120. 
human rights. On the one hand this will be achieved in the case of the Human Rights Commission through both its educational role ${ }^{104}$ and its power to investigate complaints and to assist individuals to obtain redress. ${ }^{105}$ On the other the constitutional status granted the Commission on Gender Equality promises to ensure that the continued expansion of women's participation in political and constitutional processes cannot be frustrated by a simple change in government attitudes or policy.

Finally, the constitution's recognition of traditional authorities ${ }^{106}$ and the establishment of provincial Houses of Traditional Leaders who will elect a national Council of Traditional Leaders ${ }^{107}$ goes a long way towards both the recognition of South Africa's heritage of legal pluralism as well as ensuring the representation of these particular social forces which would otherwise be excluded by the democratic process. Although with only limited consultation functions these bodies are empowered to delay legislation related to issues of their own status as traditional authorities and to indigenous law. ${ }^{108}$ More significant is the ex-officio governmental status granted to traditional leaders who are entitled to be members of local governments within whose jurisdictions they may reside. ${ }^{109}$ Again this scheme allows for a form of local autonomy based on ethnic status and provides access to governmental representation reminiscent of consociational demands formally rejected in the negotiating process.

The importance of this framework - in which power is disaggregated between many different elements - to checking any potential abuse of executive or even legislative power in the future should be fully appreciated. However, given the heavy burden South Africa's first democratic government must face in addressing the legacy of apartheid, the danger exists that these mechanisms will come to be popularly perceived as brakes designed to frustrate government attempts to address inequalities. If they are employed by those with the most access to legal resources to frustrate governmental programs their value as checks and balances on the abuse of governmental power may be undermined.

104 S. Afr. Const. (1993) section 116(1).

105 S. Afr. Const. (1993) section 116(3).

$106 \mathrm{~S}$. Afr. Const. (1993) section 181. Significantly, the recognition of traditional authonties and indigenious law has been guaranteed as a constitutional principle guiding the constitutional assembly.

107 See, S. Afr. Const. (1993) Schedule 4, Constitutional Principles XIII.

107 See, S. Afr. Const. (1993) sections 183 and 184.

108 S. Afr. Const. (1993) sections 183(2) and 184(5).

109 S. Afr. Const. (1993) section 182. 


\section{Conclusion}

Despite a formal rejection of ethnic representation and a public commitment to the building of a single national identity, the first round of South Africa's constitution-making process has left the door open to a continuing contestation over the meaning and character of South Africa's transitional constitutional framework. If considered comparatively in the light of the different strategies employed in constitutional approaches to issues of ethnic diversity described by the Ghai's, ${ }^{110}$ the 1993 Constitution seems to be a conglomerate of all three models. On the one hand it is based on constitutional review and the supremacy of individual rights and seems to presume that ethnic conflicts are merely transitional or remnants of apartheid. On the other hand it contains elements of both the intermediate model in which specific protections of cultural identity, language rights etc are designed to address minority concerns, and the second model which requires the direct allocation of political power to specific minorities or ethnic groups. Although this latter aspect of ethnic power-sharing is produced through the introduction of "neutral" mechanisms such as consensual consultation, the recognition of traditional authorities and the equal division of wards at local government level between different geographic areas, its perpetuation into the final round of constitution-making may serve to heighten demands for specific recognition of ethnically based communities by those who resist the notion of a national South African identity as the citizen's primary identity.

110

See supra text accompanying note 4 , discussion of ethnicity and constitutional frameworks in: $D$. Ghai and Y. Ghai, Ethnicity, development and democracy, in Peace and Conflict Issues After the Cold War (UNESCO, 1992) at 79; Y. Ghai, Legal Responses to Ethnicity in South and South East Asia (Univ. of Hong Kong, Mimeo); and Y. Ghai, Ethnicity and Governance in Asia: A Report to the Ford Foundation (Draft). 


\section{ABSTRACTS}

\section{South Africa's New Constitution: the Challenges of Diversity and Identity}

\section{By Heinz Klug}

The state's imposition of racial classification under apartheid made racial identity the primary political identity for most South Africans. However, during the anti-apartheid struggle and to an even greater degree during the transition towards a post-apartheid era, South Af ricans discovered that political participation is built on a far more complex, fluid set of identities and interests.

\section{Access to Justice and Related Obstacles in the French-Speaking Sub-Saharan Africa}

\section{By René Degni-Segui}

Access to justice is perceived as a fundamental right, i.e. the right to resort to judiciary power. This right is all the more important as it constitutes the condition for other rights to justice. For without a trial an accused person can not def end himself and his rights.

The application in French-speaking sub-saharan Africa of the above-mentioned right, inherited from French law, is influenced by two parameters acting in opposite directions. One of them is favourable and linked to the guarantee that this right is exercised while the other is unfavourable and leads to an application which generates clashes with African rights. This conflicting situation creates obstacles to access to justice which are related to both law and context.

Obstacles related to laws are due to

a) the fact that many defendants find themselves far away from a court. Indeed, efforts have been made by African legislators to move the justice system closer to defendants through the creation of a number of jurisdictions. Not all states have agreed to such efforts, however, and the jurisdictions which have actually been set up have not been operational.

b) the slowness of the legal proceedings which, for political and cultural reasons, may extend over several years, sometimes up to 10 years.

c) the cost of lawsuit, considering that the costly legal proceedings are not compensated for by legal counseling which still remains very limited. 